\title{
ALAT BUKTI REKAMAN SUARA DALAM PEMBUKTIAN PERKARA TINDAK PIDANA KORUPSI
}

\author{
Mansyur \\ Fakultas Hukum Universitas Borneo Tarakan \\ Jalan Pantai Amal Lama Nomor 1 Tarakan - Kalimantan Utara \\ Rico Audian Pratama Manurung \\ Fakultas Hukum Universitas Borneo Tarakan \\ Jalan Pantai Amal Lama Nomor 1 Tarakan - Kalimantan Utara
}

\begin{abstract}
ABSTRAK
Ada beberapa alat bukti yang dapat dijadikan dasar pembuktian pada tahap proses sidang pengadilan yang dilakukan untuk mencari kebenaran materiil. Alat Bukti yang sah dalam system peradilan pidana tertuang jelas pada Pasal 184 ayat (1) KUHAP, di luar itu semua maka tidak dapat dijadikan sebagai alat bukti pada tindak pidana apapun, karena wilayah KUHAP mencakup semua tindak pidana. Tetapi pada kenyataanya, ada alat bukti lain yang dapat dijadikan sebagai alat bukti yakni pada rekaman suara dalam kasus Tindak Pidana Korupsi. Penelitian ini fokus pada pengaturan standart dan kekuatan rekaman suara sebagai alat bukti dalam perkara tindak pidana korupsi.

Metode penelitian yang digunakan adalah penelitian hukum normatif, yaitu metode penelitian hukum yang dilakukan dengan meneliti bahan pustaka atau data sekunder dengan menggunakan pendekatan perundang-undangan dan pendekatan konseptual.

Hasil penelitian menunjukkan bahwa pengaturan rekaman suara dijadikan sebagai alat bukti petunjuk hal ini sesuai dengan Undang-Undang Nomor 8 Tahun 1981 tentang KUHAP, Undang-Undang Nomor 20 Tahun 2001 tentang perubahan Atas Undang-Undang Nomor 31 Tahun 1999 tentang pemberantasan TIPIKOR, Undang-Undang Nomor 11 Tahun 2008 tentang ITE, Undang-Undang Nomor 30 Tahun 2002 Tentang KPK. Standart Rekaman Suara sebagai alat bukti dalam persidangan perkara TIPIKOR, hanyalah rekaman yang dilakukan oleh KPK melalui teknik penyadapan, sedangkan rekaman suara yang diperoleh dari masyarakat atau pihak diluar KPK hanya dapat dijadikan sebagai alat bukti permulaan yang perlu dilakukan klarifikasi dengan bukti pendukung lainnya supaya dapat dikatakan cukup bukti dalam menentukan dugaan terjadinya tindak pidana korupsi.
\end{abstract}

Kata kunci: Alat Bukti, Rekaman Suara, Pembuktian, Tindak Pidana Korupsi

\section{ABSTRACT}

There is some evidence that can be used as the basis of evidence at this stage of the trial process is performed to find the material truth. Evidence of a legitimate tool in the criminal justice system clearly stated in Article 184 paragraph (1) Criminal Procedure Code, beyond that it can not be used as evidence in any criminal act, because the area of the Criminal Code covers all offenses. But in fact, there is other evidence that could be used as evidence that the sound recordings in the case of 
Corruption. This study focuses on setting standards and strength of a sound recording as evidence in the corruption case.

The method used is a normative legal research, the methods of legal research done by researching library materials or secondary data using the approach of legislation and conceptual approaches.

The results showed that the regulation sound recordings used as evidence in the instructions it is in accordance with Law No. 8 of 1981 on Criminal Procedure, Law No. 20 of 2001 on changes to Law No. 31 of 1999, Law No. 11 Year 2008, Act No. 30 of 2002. Standart Phonogram as evidence in court proceedings TIPIKOR, only recordings made by the Commission via the tapping technique, while the voice recording obtained from the community or parties outside the Commission can only be used as evidence starters necessary clarification with other supporting evidence that can be said is insufficient evidence to determine allegations of corruption.

Keywords: Evidence, Voice Recording, Evidence, Corruption

\section{Pendahuluan}

Seiring perkembangan zaman, tindak pidana juga semakin berkembang sesuai dengan kemajuan teknologi. Sehingga Penegak Hukum harus bekerja ekstra dalam mengungkap suatu kejahatan yang semakin canggih dan beraneka ragam, perlu adanya pembuktian yang sangat kuat untuk membuktikan apakah pelaku tebukti melakukan tindak pidana atau tidak. Adapun pihak yang terkait dalam sitem peradilan pidana, seperti, Polisi, Jaksa, Hakim hendaknya menguasai proses dalam Hukum Pembuktian. Lebih-lebih bagi seorang penyidik supaya dapat menentukan siapa yang patut disangka melakukan tindak pidana.

Pembuktian merupakan seperangkat kaidah hukum yang mengatur tentang pembuktian, yakni segala proses, dengan menggunakan alat-alat bukti yang sah, dan dilakukan tindakan-tindakan dengan prosedur khusus guna mengetahui fakta-fakta yuridis di persidangan, sistem yang dianut dalam pembuktian, syarat-syarat dan tata cara mengajukan bukti tersebut serta kewenangan hakim untuk menerima, menolak, dan menilai suatu pembuktian (Alfitra;2014;21).

Tugas Penyidik dalam mencari dan menemukan kebenaran materil tidaklah mudah dan untuk menuntut seseorang haruslah orang tersebut yang benar-benar diduga keras bersalah. Leden Marpaung mengatakan prinsip penghukuman adalah "Lebih baik membebaskan 1000 (seribu) orang yang bersalah daripada menghukum sesorang yang tidak bersalah tidak dapat dihindarkan untuk diterapkan" ((Leden Marpaung;2009;149). Sementara yang kita ketahui saat ini para pelaku kejahatan dalam melakukan kejahatannya sangat rapi, sehingga menyulitkan penyidik dalam mencari dan menemukan bukti yang kuat. Salah satu kasus yang menjadi sorotan di negeri ini dan sangat meresahkan masyarakat, yang memerlukan pembuktian yang sangat kuat untuk mempidanakan pelakunya adalah kasus korupsi.

Lahirnya

Komisi Pemberantasan Korupsi atau dikenal KPK pada tahun 2003 membawa perubahan baru terhadap 
penanganan tindak pidana korupsi, hal ini dapat kita lihat pengusutan dan penuntasan kasus korupsi mulai dari Aceh hingga Papua. banyak koruptor yang ditangkap dan dipenjarakan. Koruptor-koruptor tersebut antara lain, ada yang duta besar, mantan menteri, kepala lembaga/kementerian, pejabat eselon, kepala daerah, hakim, jaksa, advokat, anggota DPR/DPRD, pimpinan komisi, dan lainnya. Dengan demikian sekarang ini Indonesia menjadi Negara terkorup yang banyak koruptornya (Dyatmiko Soemodihardjo;2012;10).

Dari beberapa kasus yang terungkap bahwa korupsi di Indonesia telah melibatkan kalangan baik unsur eksekutif dan legislatif, atau dilakukan oleh pejabat publik dan politisi, sehingga mempengaruhi kesejahteraan rakyat ((Dyatmiko Soemodihardjo;2012;10). Beberapa contoh kasus korupsi di Indonesia antaranya adalah kasus Penyelewengan dana impor daging sapi yang menyebabkan kerugian Negara sebesar 1,3 Miliar oleh terdakwa Luthfi Hasan dan Ahmad Fatanah yang di vonis 16 tahun penjara (Dyatmiko Soemodihardjo;2012;10). Kemudian kasus yang masih hangat saat ini kasus Penyuapan Panitera pengadilan tata usaha negara oleh Gubernur Nonaktif Sumatera Utara Gatot Pujo Nugroho yang juga menyeret politisi Nasdem, dan beberapa pengecara (http://nasional. kompas).

$$
\text { Upaya penegakan dan }
$$

pememeriksaan Tindak Pidana Korupsi yang dilakukan oleh para pihak terkait, dengan berbagai cara. Hal ini dilakukan untuk mengungkap modus yang dilakukan oleh para pelaku. Karena biasanya banyak tindak pidana korupsi dilakukan dengan rapi. Kasus-kasus tindak pidana korupsi sulit diungkapkan karena pelakunya menggunakan peralatan yang canggih serta biasanya dilakukan oleh lebih dari satu orang dalam keadaan terselubung dan terorganisasi (Hartanti;2012;2).

Untuk melakukan pembuktian Tindak Pidana Korupsi diperlukan alat bukti yang kuat, sehingga pelaku benar-benar terbukti melakukan perbuatannya. Bukti rekaman suara merupakan alternatif untuk mengungkap perbuatan para pelaku selain Operasi Tangkap Tangan (OTT). Terdapat beberapa kasus korupsi yang pelakunya tidak dapat berkutik lagi ketika jaksa Komisi Pemberantasan Korupsi memperdengarkan bukti rekaman suara di persidangan, salah satunya kasus Suap PON Riau yakni Said Faisal didakwa karena memberikan kesaksian palsu di persidangan.

Mantan ajudan bekas Gubernur Riau Rusli Zainal tidak mampu beralibi dari dakwaan jaksa KPK yang menyebut dirinya telah memberi keterangan palsu di pengadilan. Suara Said dalam rekaman pembicaraan yang berhasil disadap oleh KPK, dinyatakan identik 90\% (Sembilan puluh persen) (www.merdeka.com). Fakta dipersidangan menyatakan bahwa keterangan saksi ahli Joko Sarwono dari Laboratorium Akustik Teknik Fisika Institut Teknologi Bandung, yang telah memberikan keterangannya bahwa, suara dalam rekaman percakapan antara Said Faisal dan Nasafwir saat penyerahan uang Rp 500 juta adalah benar suara terdakwa Said $\quad$ Faisal (https://m.tempo.co/). 


\section{Rumusan Masalah}

Berdasarkan uraian latar belakang di atas, maka penelitian ini fokus pada 2 (dua) hal berikut: pertama adalah standar rekaman suara yang dapat dijadikan sebagai alat bukti pada tindak pidana korupsi, dan kedua adalah kekuatan alat bukti rekaman suara pada tindak pidana korupsi.

\section{Tujuan Penelitian}

Tujuan penelitian ini adalah untuk mengetahui bagaimana aturan hukum meramu dalam memproyeksikan standar rekaman suara dapat dijadikan sebagai alat bukti pada tindak pidana korupsi. Tujuan yang kedua adalah untuk mengetahui bagaimana kekuatan rekaman suara yang dijadikan alat bukti pada tahap pembuktian perkara tindak pidana korupsi.

\section{Metode Penelitian}

Tipe penelitian ini adalah tergolong pada penelitian hukum normatif yakni penelitian dilakukan untuk menemukan aturan hukum dan prinsip hukum dalam mencari jawaban terhadap rumusan masalah yang telah disajikan di atas sehingga muncul preskripsi baru (Peter Mahmud Marzuki;2005;69). Proses yang dilakukan selama penelitian adalah sebagai berikut: (a) identifikasi awal terhadap rumusan masalah, (b) mengumpulkan bahanbahan pustaka, (c) kualifikasi peraturan perundang-undangan yang relevan sesuai dengan bahasan, (d) menelaah dan menganalisis, (e) merumuskan kesimpulan sebagai wujud preskirpsi baru.

\section{Konsep/Perkembangan Alat Bukti}

Konsep alat bukti menurut $\mathrm{R}$. Atang Ranomiharjo adalah segala sesuatu yang ada hubungannya dengan suatu perbuatan, dimana dengan alat-alat bukti tersebut, dapat dipergunakan sebagai bahan pembuktian guna menimbulkan keyakinan hakim atas kebenaran adanya suatu tindak pidana yang telah dilakukan oleh terdakwa (Hari Sasangka, Lili Rosita;2003;11). Sedangkan pengertian alat bukti dalam kamus hukum adalah "Segala apa yang menurut undang-undang dapat dipakai untuk membuktikan sesuatu" (R.Subekti;2005;8).

Dari awal mula munculnya alat bukti, menurut perkembangan peraturan perundang-undnagan yang berlaku adalah sebagai berikut:

1) Alat bukti yang tertuang pada pasal 295 Het Hezelane Inland Reglemend (HIR). Memuat jenis alat bukti: (1) Keterangan Saksi, (2) Surat-surat, (3) Pengakuan, dan (4) Tanda-tanda atau Petunjuk.

2) Kitab Undang-undang Hukum Acara Pidana (KUHAP), macammacam alat bukti diatur dalam pasal 184 KUHAP, yaitu: (1) Keterangan saksi, (2) Keterangan ahli, (3) Surat, (4) Petunjuk, dan (5) Keterangan terdakwa.

3) Undang-Undang Nomor 11 Tahun 2008 tentang Informasi Transaksi Elektronik (ITE), yaitu: (1) Alat bukti sebagaimana yang dimaksud dalam ketentuan perundang-undangan; dan (2) Alat bukti lain berupa informasi elektronik dan/atau dokumen elektronik dan hal yang telah diketahui oleh umum (Alfitra;2014;30-36).

4) Undang-Undang Nomor 20 Tahun 2001 tentang Perubahan Atas Undang-Undang Nomor 31 Tahun 1999 Tentang Pemberantasan Tindak Pidana Korupsi (Pasal 
26A) memuat: (1) alat bukti lain yang berupa informasi yang diucapkan, dikirim, diterima, atau disimpan secara elektronik dengan alat optic atau yang serupa dengan itu, dan (2) dokumen, yakni setiap rekaman data atau informasi yang dapat dilihat, dibaca, dan/atau didengar yang dapat dikeluarkan dengan atau tanpa bantuan suatu sarana, baik yang tertuang dalam kertas, benda fisik apa pun selain kertas maupun yang terekam secara elektronik yang berupa tulisan, suara, gambar, peta, rancangan, foto, huruf, tanda, angka, atau perforasi yang memiliki makna.

Putusan Mahkamah Konstitusi Nomor 20/PUU-XIV/2016 bahwa alat bukti Informasi Elektronik dan/atau Dokumen Elekronik merupakan perluasan dari alat bukti pasal 184 KUHAP. Sepanjang dimaknai Informasi Elektronik dan/atau Dokumen Elektronik sebagai alat bukti yang dilakukan dalam rangka penegakan hukum atas permintaan kepolisian, kejaksaan, dan/atau penegak hukum lainnya yang ditetapkan berdasarkan UndangUndang sebagaimana ditentukan dalam Pasal 31 ayat (3) UndangUndang Nomor 11 Tahun 2008 Tentang ITE.

Pengajuan alat bukti yang sah dipersidangan menurut undangundang yang berlaku dapat dilakukan oleh Penuntut umum dengan tujuan untuk membuktikan dakwaannya dan Terdakwa atau penasihat hukum, jika ada alat bukti yang bersifat meringan kan, untuk meringankan atau membebaskan terdakwa.

Pada dasarnya yang berhak mengajukan alat bukti dalam persidangan adalah penuntut umum (alat bukti yang memberatkan/ acharge) dan terdakwa atau penasihat hukum (jika ada alat bukti yang bersifat meringankan/ adercharge), terdakwa tidak dibebani kewajiban pembuktian, hal ini merupakan jelmaan asas praduga tidak bersalah. Jadi, pada prinsipnya yang membuktikan kesalahan terdakwa adalah penuntut umum ((Alfitra;2014;30-36).

\section{Rekaman Suara}

Rekaman berasal dari kata dasar rekam, dalam Kamus Besar Bahasa Indonesia berarti alur-alur bunyi (suara) pada piringan hitam, dan sebagainya. Rekaman berarti suatu yang dapat direkam dapat berupa suara, gambar atau cetakan dan sebagainya. Media rekaman ini biasanya berupa suara musik, suara manusia, suara binatang atau yang lainnya (Wahyu Untara;2014;421). Sedangkan suara adalah istilah yang digunakan dalam ilmu fonetik dan fonologi untuk mencirikan bunyi bahasa. Bunyi atau suara adalah kompresi mekanikal atau gelombang longitudinal yang merambat melalui medium. Medium atau zat perantara ini dapat berupa zat cair, padat, gas. Jadi, gelombang bunyi dapat merambat misalnya didalam air, batu bara, atau udara (Dwi Nurcahyo;2012;2).

Dari pengertian diatas, dapat disimpulkan bahwa rekaman suara merupakan suatu alat yang dapat menyimpan gelombang bunyi sebagaimana kita sering menyebut sebagai suara jika hal tersebut sampai pada telinga manusia maupun hewan melalui berbagai media seperti udara, air dan lain sebagainya. Sesuai dengan perkembangan teknologi, maka manusia menciptakan alat 
perekam supaya suara dapat diputar kembali sebagai alat bantu untuk memutar memori atas apa yang telah manusia dengar.

Rekaman Suara berkembang secara bertahap seiring perkembangan teknologi. Alat perekam suara pertama yaitu Phonautograph penemuan Leon Scott. Phonautograph telah ada sebelum phonograph penemuan Thomas Alpha Edison yang digunakan untuk mempelajari gelombang suara. Pada tahun 1870an Thomas Alpha Edison mendapat ide untuk mencetak pesan telepon diatas kertas berlapis material halus seperti bahan lilin berbentuk silinder dengan pemutaran rekaman menggunakan alat elektromagnetik yang berbentuk jarum. Setelah penemuan tersebut, muncullah alat perekam lain Graphophone. Tahun 1894, Emir Berliner mengembangkan Phonograph menjadi Graphophone untuk mencetak suara diatas piringan dan bukan pada silinder dengan alasan lebih mudah diproduksi (Ambrosius Yuniart Lefaan). Tahun 1898, magnetic recording diperkenalkan oleh Valdemar Poulsen dengan menggunakan Telegraphone. Dengan menggunakan kekuatan magnet yang bergerak secara konstan melewati head perekam dan menghasilkan pola yang serupa dengung sinyal. Menghasilkan suara yang lebih baik dari teknologi baik dari teknologi sebelumnya. Tahun 1932 tape recording mulai dikembangkan di jerman. Tape recording mulai popular tahun 1950an. Tahun 1940-an, mulainya eksperimen dengan menggunakan Mutirack recording. Dengan adanya Multirac recording, teknik merekam dengan memisahkan suara dapat dilakukan. Tahun 1980-an teknologi digital recording mulai berkembang. Pada tahun 1980-an, budaya rekaman sudah mencapai era yang sangat berubah dari budaya awal. Dengan segala kemudahan menggunakan peralatan multimedia yang sudah berupa file midi (Ambrosius Yuniart Lefaan;15).

\section{Tindak Pidana Korupsi}

Korupsi berasal dari bahasa latin corruption atau corruptus, dan dalam bahasa latin yang lebih tua dipakai istilah corrumpere. Dari bahasa latin itulah turun ke berbagai bahsa bangsa-bangsa di Eropa, seperti Inggris: corruption, corrupt; Perancis: corruption; dan Belanda: corruptie atau korruptie, yang kemudian turun kedalam bahasa Indonesia menjadi korupsi. Arti harfiah dari kata itu ialah kebusukan, keburukan, kebejatan, ketidakjujuran, dapat disuap, tidak bermoral, penyimpangan dari kesucian (Tumbur Ompu Sunggu;2012;2).

Ada beberapa pendapat mengemukakan tentang pengertian korupsi yang dikutip oleh IGM. Nurdjana, yakni menurut Partanto dan Al Barry menyatakan bahwa, Korupsi dalam kamus ilmiah popular mengandung pengertian kecurangan, penyelewengan/penyalahgunaan jabatan untuk kepentingan diri, pemalsuan. Martiman Prodjohamidjojo menyatakan sebagai berikut : Korupsi dari sudut pandang teori pasar, menurut Jacop Van Klavaren, adalah jika seorang pengabdi Negara (pegawai negeri) menganggap kantor/instansinya sebagai perusahaan dagang, sehingga dalam pekerjaannya akan diusahakan memperoleh pendapatan sebanyak mungkin. Sehubungan dengan titik 
berat jabatan pemerintahan, M.Mc. Mullan menyatakan bahwa seorang pejabat pemerintahan dikatakan korup apabila menerima uang sebagai dorongan untuk melakukan sesuatu yang sebenarnya bisa dilakukan dalam tugas jabatannya, padahal ia tidak diperbolehkan melakukan hal seperti itu dalam menjalankan tugasnya (IGM. Nurdjana;2003;8). Subekti dan Tjitro soedibio dalam kamus hukum Korupsi adalah dengan melakukan suatu tindak pidana memperkaya diri sendiri yang secara langsung atau tidak langsung merugikan keuangan/ perekonomian Negara (R. Subekti dan Tjitrosoedibio;69).

\section{Pembahasan \\ Standard Rekaman Suara sebagai Alat Bukti dalam Pembuktian Perkara Tindak Pinana}

Tindak pidana korupsi merupakan sebuah tindak pidana kerah putih (white collar crime) yang berarti pelakunya adalah orang-orang yang terdidik dimasing-masing bidang, bersifat (extra ordinary crime), merupakan sebuah kejahatan yang luar biasa besar dan berdampak sangat buruk sekali bagi suatu bangsa, merupakan sebuah kejahatan yang teroganisir secara rapi (organizer criem), dan merupakan kejahatan dengan dimensi baru (new dimention of crime) (Aziz Syamsudin ;2011;137).

Hal ini yang membuat tindak pidana korupsi sangat sulit untuk diungkap apalagi untuk mencari alat bukti agar pelaku dapat dijerat hukum. Oleh karena sulitnya mendapatkan alat bukti maka dibutuhkan cara-cara atau metode baru, salah satunya adalah dengan melakukan penyadapan yang hanya dapat dilakukan oleh KPK, sesuai dengan Undang-Undang Nomor 30 Tahun 2002 Tentang Komisi Pemberantasan Korupsi Pasal 12 huruf a yang berbunyi, dalam melaksanakan tugas penyelidikan, penyidikan, dan penuntutan sebagaimana dimaksud dalam Pasal 6 huruf c, Komisi Pemberantasan Korupsi berwenang untuk melakukan penyadapan dan merekam pembicaraan.

Penggunaan alat bukti elektronik (alat bukti hasil penyadapan berupa rekaman suara) diaukui sebagai salah satu alat bukti petunjuk dalam tindak pidana korupsi, hal ini sesuai dengan Undang-Undang Nomor 20 Tahun 2001 tentang perubahan UndangUndang Nomor 31 Tahun 1999 tentang tindak pidana korupsi. Sebagaimana dijelaskan dalam pasal 26 A sebagai berikut:

\section{Pasal26A}

Alat bukti yang sah dalam bentuk petunjuk sebagaimana dimaksud dalam pasal 188 ayat 2 Undang-Undang Nomor 8 Tahun 1981 tentang Hukum Acara Pidana, khusus tindak pidana korupsi juga dapat di peroleh dari:

a. Alat bukti lain yang berupa informasi yang diucapkan dikirim, diterima atau disimpan secara elektronik dengan alat optic atau yang serupa dengan itu dan

b. Dokumen, yakni setiap rekaman data atau informasi yang dapat dilihat, dibaca dan atau didengarkan yang dapat dikeluarkan dengan atau tanpa bantuan suatu sarana, baik yang tertuang diatas kertas, maupun yang terekam secara elektronik, yang berupa tulisan, suara, 
gambar, peta, rancangan, foto, huruf, tanda, angka atau informasi yang memiliki makna.

Inilah yang membedakan antara alat bukti dalam KUHAP dan alat bukti dalam Undang-Undang tindak pidana korupsi, hal ini sesuai dengan pasal 39 Undang-Undang Nomor 30 Tahun 2002 tentang Komisi Pemberantasan Tindak Pidana Korupsi yang menyatakan adanya kekhususan mengenai alat bukti.

\section{Pasal 39}

(1) Penyidikan, penyelidikan dan penuntutan tindak pidana korupsi dilakukan berdasarkan hukum acara pidana yang berlaku dan berdasarkan Undang-Undang Nomor 31 Tahun 1999 tentang Pemberantasan Tindak Pidana Korupsi sebagaimana telah diubah dengan Undang-Undang Nomor 20 Tahun 2001 tentang perubahan atas Undang-Undang Nomor 31 tentang pemberantasan tindak pidana korupsi, kecuali ditentukan lain dalam Undang-Undang ini.

Hal ini menunjukkan bahwa alat bukti petunjuk pada tindak pidana korupsi juga bisa didapat melalui informasi elektronik dan dokumen elektronik yang memiliki kedudukan yang sama dengan alat bukti keterangan saksi, surat dan keterangan terdakwa sebagai penyusun alat bukti petunjuk.

Hasil penyadapan yang dilakukan oleh KPK dalam mengungkap kasus korupsi yang selama ini dilakukan berdasarkan ketentuan mengenai alat bukti yang sah selanjutnya akan menentukan kekuatan alat bukti tersebut. Hasil penyadapan yang dilakukan oleh KPK selama ini merupakan sebuah alat bukti petunjuk sebagai mana yang diterangkan dalam Undang-Undang Nomor 20 Tahun 2001 tentang perubahan Undang-Undang Nomor 31 Tahun 1999 tentang tindak pidana korupsi Pasal 26A diatas. Alat bukti petunjuk digunakan seorang hakim apabila belum mencukupi batas minimum hukum pembuktian sebagaimana yang tercantum dalam pasal 183 KUHAP.

Alat bukti petunjuk dapat digunakan apabila didukung oleh alat bukti lain berupa alat bukti keterangan saksi, keterangan ahli, alat bukti surat dan alat bukti keterangan terdakwa. Hal ini menunjukkan bahwa alat bukti elektronik berupa rekaman suara dari hasil penyadapan, dapat dikatakan merupakan perluasan alat bukti petunjuk yang terdapat dalam pasal 184 KUHAP mengenai alat bukti.

Pengakuan alat bukti elektronik juga terdapat dalam pasal 5 ayat (1) dan (2) Undang-Undang Nomor 11 Tahun 2008 tentang Informasi dan Transaksi elektronik yang berbunyi sebagai berikut:

1. Informasi Elektronik dan/atau dokumen elektronik dan/atau hasil cetaknya merupakan alat bukti hukum yang sah.

2. Informasi elektronik dan/atau dokumen elektronik dan/atau hasil cetakannya, merupakan perluasan dari alat bukti yang sah sesuai dengan hukum acara yang berlaku di Indonesia.

Pemahaman perluasan tersebut dihubungkan dengan pasal 5 ayat (1) Undang-Undang Nomor 11 Tahun 2008 tentang Informasi dan Transaksi Elektronik. Perluasan yang dimaksud adalah sebagai berikut: 
a. Memperluas jumlah alat bukti yang diatur dalam Undang-Undang Nomor 8 Tahun 1981 tentang Hukum Acara Pidana, berdasarkan Pasal 5 Undang-Undang Nomor 11 Tahun 2008 maka alat bukti ditambah satu alat bukti yaitu alat bukti informasi dan transaksi Elektronik.

b. Memperluas cakupan alat bukti yang diatur dalam Undang-Undang Nomor 8 Tahun 1981 tentang Hukum Acara Pidana, hasil cetakan Informasi elektronik dan dokumen elektronik secara hakiki ialah surat.

c. Perluasan ektronik juga dimaksudkan bahwa Informasi Elektronik atau dokumen Elektronik sebagai sumber petunjuk sebagaimana dimungkinkan dalam beberapa Undang-Undang.

Rekaman Suara dapat digolongkan sebagai informasi elektronik atau dokumen elektronik berdasarkan Undang-Undang Nomor 11 Tahun 2008 tentang Informasi dan Transaksi Elektronik. Pasal 1 ayat (1) dan ayat (4), yang berbunyi:

Ayat (1)

"Informasi elektronik adalah satu atau sekumpulan data elektronik, termaksuk tetapi tidak terbatas pada tulisan, suara, gambar, peta, rancangan, foto, electronic data interchange (EDI), surat elektronik (electronic mail), telegram, teleks, telecopy atau sejenisnya, huruf, tandam angka, kode akses, symbol, atau perforasi yang telah diolah yang memiliki arti atau dapat dipahami oleh orang yang mapu memahaminya" Ayat (4)

"Dokumen elektronik adalah setiap informasi elektronik yang dibuat, diteruskan, dikirimkan, diterima, atau disimpan dalam bentuk analog, digital, elektromagnetik, optikal atau sejenisnya, yang dapat dilihat, ditampilkan, dan/atau didengar melalui computer atau system elektronik, termasuk tetapi tidak terbatas dalam tulisan, suara, gambar, peta, rancangan, foto atau sejenisnya, huruf, angka, kode, akses, symbol atau perforasi yang memiliki makna atau arti atau dapat dipahami oleh orang yang mampu memahaminya"

\section{Kekuatan Alat Bukti Rekaman Suara}

Rekaman Suara sebagai alat bukti perlu keabasahan yang kuat, sehingga meyakinkan hakim dalam menjatuhkan putusannya. Selain Undang-Undang No 20 Tahun 2001 tentang Pemberantasan Tindak Pidana Korupsi Pasal 26 A yang menyebutkan bahwa alat bukti yang disimpan secara elektronik dapat dijadikan alat bukti yang sah dalam kasus tindak pidana korupsi. UU ITE juga memperjelas Rekaman Suara (informasi dokumen elektronik) sebagai alat bukti yang sah di pengadilan.

Selain

informasi/dokumen elektronik sebagai alat bukti, UU ITE juga mengakui print out atau hasil cetak sebagai alat bukti hukum yang sah. Rekaman Suara yang merupakan Informasi elektronik dan dokumen elektronik dinyatakan sah apabila menggunakan system elektronik yang memenuhi persyaratan minimum, berdasarkan Pasal 5 ayat (3) jo Pasal 6 Nomor 11 Tahun 2008 tentang ITE berbunyi:

a. Dapat menampilkan kembali informasi elektronik dan atau dokumen elektronik secara utuh sesuai dengan masa retensi yang 
ditetapkan dengan peraturan perundang-undangan;

b. Dapat melindungi ketersediaan, keutuhan, keontentikan kerahasiaan dan keteraksesan informasi elektronik tersebut; dan

c. Dapat beroperasi sesuai dengan prosedur dan petunjuk yang diumumkan dengan bahasa, informasi, atau symbol yang dapat dipahami oleh pihak yang bersangkutan dengan penyelenggara sitem elektronik tersebut dan memiliki mekanisme yang berkelanjutan untuk menjaga kebaruan, kejelasan, dan kebertanggungjawaban prosedur dan petunjuk.

Rekaman suara diakui

keabsahannya apabila telah memenuhi unsur-unsur tersebut, sehingga bukti rekaman suara tidak dapat di ragukan. Namun yang menjadi pemersalahan apakah bukti rekaman suara itu asli atau hasil duplikasi? Menyikapi hal ini perlu dilakukan audit atas rekaman suara tersebut. Jika suatu rekaman suara sudah diaudit atau disertifikasi oleh suatu badan standar maka alat bukti rekaman suara tersebut tidak bisa disangkal dan dapat dijadikan alat bukti.

Berdasarkan hal tersebut KPK yang memiliki kewenangan melakukan penyadapan, biasanya membawa hasil sadapan tersebut ke Ahli Digital Forensic ITB, Dari rekaman suara, orang yang melakukan Percakapan dapat diketahui identitasnya melalui pemeriksaan audio forensic, forensic ini berkaitan dengan rekaman suara pelaku kejahatan, rekaman biasanya diperiksa untuk kepentingan voice recognition, yaitu memeriksa dan menganalisis suara yang ada didalam rekaman (dikenal dengan unknown sample), yang kemudian dibandingkan dengan suara pembanding (known samples) dalam rangka untuk menegetahui apakah suara unknown adalah identik atau tidak identik dengan suara known. Jika identik maka suara barang bukti berasal dari subjek pembanding, dan sebaliknya. Jika tidak identik, maka suara tidak berasal dari subjek pembanding (Muhammad Nuh ALAzhar;2012;26).

Dengan prosedur penanganan rekaman suara yang benar, kemudian dilanjutkan dengan pemeriksaan dan analisisnya yang procedural, diharapkan hasil pemeriksaan audio forensic untuk voice recognition dapat menunjukan secara ilmiah kepemilikan suara yang ada dalam rekaman tersebut untuk disajikan sebagai alat bukti kuat dipengadilan. Dalam hal ini peran ahli dalam pemeriksaan perkara, baik pada tingkat penyidikan maupun persidangan tidak dapat diabaikan begitu saja. Keterangan ahli sangat berguna dalam mengungkap perkara Tindak Pidana Korupsi, untuk mendapatkan keyakinan tentang suara siapa yang berbicara dalam rekaman tersebut, sehingga menguatkan alat bukti petunjuk yang ada di dalam pasal 26 A yang mengakui Informasi elektronik dan dokumen elektronik (Rekaman Suara) sebagai alat bukti petunjuk.

\section{Simpulan}

Dasar rekaman suara sebagai alat bukti petunjuk pada Tindak Pidana Korupsi adalah UndangUndang Nomor 8 Tahun 1981 tentang Kitab Undang-Undang Hukum Acara Pidana, Undang-Undang Nomor 20 Tahun 2001 tentang perubahan Atas 
Undang-Undang Nomor 31 Tahun 1999 tentang pemberantasan Tindak Pidana Korupsi, Undang-Undang Nomor 11 Tahun 2008 tentang Informasi dan Transaksi Elektronik, Undang-Undang Nomor 30 Tahun 2002 Tentang Komisi Pemberantasan Korupsi. Sedangkan Standart Rekaman Suara yang dapat dijadikan alat bukti dalam persidangan perkara TIPIKOR, hanyalah rekaman yang berasal dari sadapan KPK, sedangkan rekaman suara yang direkam oleh seseorang atau masyarakat hanya dapat dijadikan sebagai alat bukti permulaan.

Rekaman Suara dapat menjadi alat bukti petunjuk sepanjang rekaman suara tersebut ada persesuaiannya dengan alat bukti lain misalnya dari keterangan saksi, surat, dan keterangan terdakwa. Kemudian untuk menguatkan hakim dalam proses pembuktian mengenai kebenaran dari rekaman suara tersebut, hakim memerlukan seorang ahli Digital Forensic untuk dimintai keterangannya guna keyakinan kepada hakim.

\section{Daftar Pustaka}

\section{Buku}

Alfitra. Hukum Pembuktian dalam Beracara Pidana, Perdata,dan Korupsi di Indonesia. Raih Asa Sukses, Jakarta, 2014.

Ambrosius Yuniart Lefaan, Landasan Konseptual Perencanaan Studio Rekaman Musik di Yogyakarta, Skripsi Fakultas Tekhnik Universitas Atma Jaya Yogyakarta.

Aziz Syamsudin, Tindak Pidana Khusus, Sinar Grafika, Jakarta, 2011.

Dwi Nurcahyo, Analisis Proses "Studio Home Recording" Dalam
Pembuatan Lagu Jalan Sendiri

The Mad Band, Naskah

Publikasi, Jurusan Sistem

Informasi Sekolah Tinggi

Manajemen Informatika Dan

Komputer AMIKOM, 2012.

Dyatmiko Soemodihardjo,

Memberantas Korupsi Di

Indonesia, Shira Media, Yogyakarta, 2012.

Evi Hartanti, Tindak Pidana Korupsi Edisi Kedua, Sinar Grafika, Jakarta, 2012.

Hari Sasangka, Lili Rosita, Hukum Pembuktian Dalam Perkara Pidana, Mandar Maju, Bandung.

IGM. Nurdjana, Korupsi Dalam Praktek Bisnis, PT. Gramedia Pustaka Utama, Jakarta, 2003.

Leden Marpaung, Proses Penanganan Perkara Pidana (Penyelidikan dan Penyidikan), Sinar Grafika, Jakarta, 2009.

Muhammad Nuh AL-Azhar, Digital Forensik Panduan Praktis Investigasi Komputer, Salemba Infotek, Jakarta, 2012.

Peter Mahmud Marzuki, Penelitian Hukum, Kencana PMG, Jakarta, 2005.

R.Subekti, Kamus Hukum, Jakarta: Pradnya Pramita, 2005.

Tumbur Ompu Sunggu, Keberadaan Komisi Pemberantasan Korupsi Dalam Penegakan Hukum Di Indonesia, Total Media, Yogyakarta, 2012.

Wahyu Untara, Kamus Bahasa Indonesia: Edisi Revisi, Indonesia Tera, Yogyakarta, 2014.

\section{Peraturan Perundang-Undangan}

Undang-Undang Republik Indonesia Nomor 8 Tahun 1981 tentang Kitab Undang-Undang Hukum Acara Pidana (KUHAP).( Lembaran Negara Republik 
Indonesia Tahun 1981 Nomor 76, Tambahan Lembaran Negara Republik Indonesia Nomor 3258).

Undang-Undang Republik Indonesia Nomor 20 Tahun 2001 tentang Perubahan atas Undang-Undang Nomor 31 Tahun 1999 tentang Pemberantasan Korupsi. (Lembaran Negara Republik Indonesia Tahun 2001 Nomor 134, Tambahan Lembaran Negara Republik Indonesia Nomor 4150).

Undang-Undang Republik Indonesia Nomor 30 Tahun 2002 Tentang Komisi Pemberantasan Korupsi. (Lembaran Negara Republik Indonesia Tahun 2002 Nomor 137, Tambahan Lembaran Negara Republik Indonesia Nomor 4250).

Undang-Undang Republik Indonesia Nomor 4 Tahun 2004 Tentang Kekuasaan Kehakiman. (Lembaran Negara Republik Indonesia Tahun 2004 Nomor 8).

Undang-Undang Republik Indonesia Nomor 11 Tahun 2008 Informasi Transaksi Elektronik. (Lembaran Negara Republik
Indonesia Tahun 2008 Nomor 58, Tambahan Lembaran Negara Republik Indonesia Nomor 4843).

\section{Internet}

http://www.tribunnews.com/nasion al/2013/pks-heran-vonisluthfi-hasan-lebih-beratdibandingkan-nazaruddin. Diakses Tanggal 23 Maret 2016 Pukul 20;40 Wita).

http://nasional. kompas. com/read/2016/03/14/09021 311/Gatot .Pujo. dan. Istrinya. Hadapi. Vonis. Hakim. pada.Hari.Ini. (Diakses Tangal 23 Maret 2016 Pukul 21;00 Wita).

http://www.merdeka.com/peristiwa /rekaman-suara-identikajudan-rusli-zainal-tak-bisamengelak.html.

(Diakses Tanggal 23 Maret 2016 Pukul 21;05 Wita).

https://m.tempo.co/read/news/201 4/07/07/058591102/berboho ng-ajudan-gubernur-riaudivonis-7-tahun-bui. (Diakses Tanggal 23 Maret 2016 Pukul 21;10 Wita). 